UDC 539.3/6

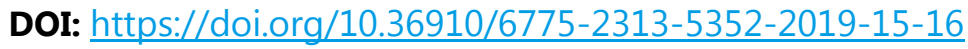

Yu.S. Kholodnyak, Ph.D., S.V. Podlesny, Ph.D., S.V. Kaporovych, Ph.D., Ye.D. Korotenko, Ph.D.

Donbass State Engineering Academy

\title{
ON APPLICATION OF A SIMPLIFIED TWO-DIMENSIONAL MODEL OF FORCED OSCILLATIONS TO THE POWER ANALYSIS OF FLAT STEELWORKS
}

Abstract. An analysis of existing methods of power calculation of steelworks under the influence of forced oscillations is performed. When considering the forced oscillations of flat steelworks, twodimensional models are used, which are complex for wide practical use. Their implementation requires in-depth mathematical training and complex computational tools. The aim of this work is to develop a simplified two-dimensional mathematical model of forced oscillations of flat steelworks with following use of this model in power calculations. The mathematical model proposed in this paper describes oscillations of a weightless steelwork with a point mass of simultaneous action in vertical and horizontal harmonic disturbing forces acting on them. The model is based on the method of forces, establishes a link between the movements of the steelworks and the forces that act on them. Together with the model the dependences for calculating the resonant frequencies of the oscillatory system are obtained. The performed developments allow to determine the dynamic characteristics of the oscillatory process and to calculate a steelwork strength, stiffness and stability.

Keywords: plane steelworks, forced oscillations, mathematical model, resonant frequencies, power calculations.

Introduction and statement of the problem. Scientific and technological progress requires the designers to apply increasingly sophisticated methods of calculation regarding the strength and power parameters of the products created. Such requirements are most relevant for structures subject to external loads variable in time.

In industry rod structures are considerably widespread, such as beams, flat frameworks and steelworks, employed under conditions of forced oscillations, i.e. arising from the action of so-called disturbing forces. Most often the source of such forces is the work of various equipment installed on these structures - pumps, presses, pile drivers, etc. The disturbing forces result from the movement of the center of mass of such equipment and they are of periodic, often harmonious, nature.

Constructions under forced oscillations undergo additional (dynamic) forces and stresses, which in some cases reach considerable quantities. Hence is the importance of adequate consideration of such structures in power calculations.

As a rule, forced vibrations of a weightless beam with a fixed point mass are analyzed in the educational and methodical literature on the resistance of materials [1-3]. This (simplified) model of the oscillatory system is a single-dimensional one. In spite of its simplicity, it provides acceptable accuracy of power calculations for general practice. Along with it, more sophisticated one-dimensional models are also offered in university courses of resistance of materials and structural mechanics, which take into consideration point mass and beam weight [4-6]. However, the proposed calculation methods for widespread practical application are quite complex, since they require advanced mathematical training, which usually goes beyond the curriculum of higher engineering institutions.

Forced vibrations of flat frameworks and steelworks are generally considered in University courses of construction mechanics [7-13]; wherein complex two-dimensional models are used, which are also not acceptable for widespread practical use. This requires simpler calculation techniques which do not require special mathematical training but still provide acceptable practice for accuracy.

Such a two-dimensional model of forced oscillations was created by the authors of the paper and adapted to calculations of the strength of flat frames [14, 15].

Results of the work. In this model the oscillating mass and oscillation source is a statically unbalanced rotor of an electric motor, but other options are also possible.

When operating such an engine a centrifugal force of inertia $\bar{H}$ arises, which is a disturbing force of oscillation. It rotates with the rotor of the engine with circular frequency $\omega$. In addition to it the force of gravity $m \bar{g}$ and the inertia forces $\bar{\Phi}_{1}$ and $\bar{\Phi}_{2}$ as well as the resistance of the medium $\bar{F}_{1}$ and $\bar{F}_{2}$ and reaction of the elastic element $\bar{R}_{1}$ and $\bar{R}_{2}$ influence the oscillating mass $m$. Fluctuations occur around the position of static equilibrium - point $O$ (Fig. 1).

(C) Yu.S. Kholodnyak, S.V. Podlesny, S.V. Kaporovych, Ye.D. Korotenko 


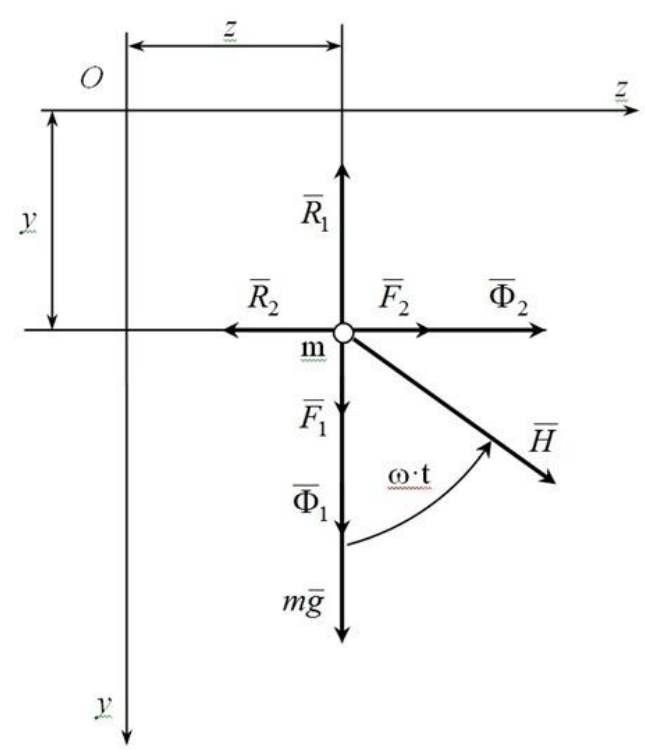

Figure 1. Scheme of oscillating mass load

According to the D'Alembert principle [4], the oscillating mass at any time is in kinetostatic equilibrium under the action of the force applied to it (see Fig. 1). The vector equation of this equilibrium is:

$$
m \bar{g}+\bar{R}_{1}+\bar{R}_{2}+\bar{\Phi}_{1}+\bar{\Phi}_{2}+\bar{F}_{1}+\bar{F}_{2}+\bar{H}=0
$$

The differential equations of motion of an oscillating mass are transformed projections on the axis of coordinates of the vector equation (1):

$$
\begin{gathered}
m \cdot \ddot{y}+\mu \cdot \dot{y}+f_{1}(y, z)=m g+H \cdot \cos (\omega \cdot t), \\
m \cdot \ddot{z}+\mu \cdot \dot{z}+f_{2}(y, z)=H \cdot \sin (\omega \cdot t),
\end{gathered}
$$

where $\dot{y}$ and $\dot{z}$ are current projections of the velocity of the oscillating mass on the corresponding axes of coordinates;

$\ddot{y}$ and $\ddot{z}$ are current projections of the acceleration of the oscillating mass on the corresponding axes of coordinates;

$\mu$ is the coefficient of the medium resistance;

$t$ is the time from the start of the movement, i.e. the exit of mass $m$ from the position of static equilibrium;

$$
\begin{gathered}
f_{1}(y, z)=R_{1}=P_{1}=m g+\frac{z}{\delta_{21}}-\frac{y \cdot \delta_{21}-z \cdot \delta_{11}}{\delta_{21}^{2}-\delta_{22} \cdot \delta_{11}} \cdot \frac{\delta_{22}}{\delta_{21}} ; \\
f_{2}(y, z)=R_{2}=P_{2}=\frac{y \cdot \delta_{21}-z \cdot \delta_{11}}{\delta_{21}^{2}-\delta_{22} \cdot \delta_{11}} ;
\end{gathered}
$$

where $P_{1}$ and $P_{2}$ are the forces with which the oscillating mass influences on the elastic element;

$\delta_{11}, \delta_{22,}, \delta_{12}=\delta_{21}$ are peculiar stiffness indices of the elastic element; for the frameworks, they are determined by Vereshchagin's rule or by the universal formula of multiplication of trapeziums (formula of extreme ordinates), using the corresponding graphs of bending moments [16].

Differential equations (2) and (3) require implication of any of the existing computing systems for their integration. The simplest and most acceptable in this case is the Mathcad system, which allows performing all the necessary calculations. To integrate these equations, it is convenient to accept zero initial conditions, as well as the condition $\omega_{0}=\omega$, i.e. consider the period of acceleration of the motor to be absent.

The numerical integration of these equations determines implicitly the laws of motion of oscillating mass $y=y(t)$ and $z=z(t)$, and through them, the laws of change of forces of the action of oscillating mass on an elastic element $P_{1}=P_{1}(t)$ and $P_{2}=P_{2}(t)$ and their maximum values, which further serve to evaluate the strength of the structure. 
The created model also allows to determine the circular frequencies of natural oscillations of the structure, which is called resonant frequencies for brevity. They are calculated by the formula:

$$
\omega_{1,2}=\frac{\sqrt{2}}{\sqrt{m \cdot\left(\delta_{11}+\delta_{22}\right) \pm m \cdot \sqrt{\left(\delta_{11}+\delta_{22}\right)^{2}-4 \cdot\left(\delta_{11} \cdot \delta_{22}-\delta_{12}^{2}\right)}}}
$$

Apparently, application of the outlined model is not limited to frameworks. This model is a versatile one and is fundamentally acceptable to any of the oscillating systems with point mass and non-weighted elastic element of arbitrary construction with two degrees of freedom.

The purpose of this work is to adapt the model to the power calculations of flat steelworks under conditions of forced oscillations.

The main difference between steelworks and frameworks is that the rods in the steelworks are connected to each other in the so-called hubs by means of hinges, and the frameworks are rigidly fastened, making the rods of the steelworks stretch and contract, whereas the frameworks (if longitudinal forces not taken to attention) are under conditions of flat bending. Therefore, the steelworkes stiffness indices, in contrast to those of the frames, in which these indices depend mainly on bending moments, are determined by the longitudinal force $N$.

The differences of steelworks should also include the possibility of longitudinal bending in compressed rods, that is, loss of stability, which inevitably renders the structure unusable for further use.

Dependencies arising from Vereshchagin's rule for longitudinal force diagrams are used to determine steelwork rigidity [16]:

$$
\left\{\begin{array}{l}
\delta_{11}=\frac{1}{E \cdot F} \cdot \sum_{i=1}^{n} \bar{N}_{i}^{2} \cdot \ell_{i} ; \\
\delta_{22}=\frac{1}{E \cdot F} \cdot \sum_{i=1}^{n}\left(\bar{N}_{i}^{\prime}\right)^{2} \cdot \ell_{i} ; \\
\delta_{12}=\delta_{21}=\frac{1}{E \cdot F} \cdot \sum_{i=1}^{n} \bar{N}_{i} \cdot \bar{N}_{i}^{\prime} \cdot \ell_{i},
\end{array}\right.
$$

where $i$ is the rod's number;

$n$ is the number of rods in the steelwork;

$\bar{N}_{i}$ is the force in the $\mathrm{i}$-th rod from the action of vertical unit force $P_{l}=1$, which is applied to the steelwork at the location of the oscillating mass;

$\bar{N}_{i}^{\prime}$ is the force in the $\mathrm{i}$-th rod from the action of horizontal unit force $P_{2}=1$ applied to the same place;

$\ell_{i}$ is the length of the $\mathrm{i}$-th rod;

$E$ is elasticity modulus of rod material;

$F$ is the cross-sectional area of the steelwork rods.

Note that steelworks located in the vertical plane and having the same cross-sectional shape and cross-sectional dimensions are considered here.

To determine the values $\bar{N}_{i}$ and $\bar{N}_{i}^{\prime}$, it is necessary to pre-calculate the reference reactions of the steelwork, and then apply the cut-off method or section method proposed by Ritter [7].

Having identified the pair of forces thus indicated in each of the rods and having analyzed the combinations of their values, it is necessary to identify the rods which are potentially dangerous from the point of view of compression strength and resistance. This is where attention should be paid to at the appropriate stages of power calculations.

The specificity and details of testing and design calculations of flat steelworks for strength and stability using a simplified two-dimensional forced vibration model will be illustrated by the following examples.

Example 1. Ignoring the resistance of the medium, verify the strength, stability and resonance of a flat steelwork (Fig. 2) made of pipes with an outer diameter $d=100 \mathrm{~mm}$ and a wall thickness $s=5 \mathrm{~mm}$. Pipe material is steel St.3, $[\sigma]=160 \mathrm{MPA}$. The mass of a static unbalanced electric motor installed on the steelwork is $m=2000 \mathrm{~kg}$, its circular speed $\omega=31.4 \mathrm{~s}^{-1}(300 \mathrm{rpm})$, the modulus of the force generated is $H=0.3 \mathrm{mg}$. 


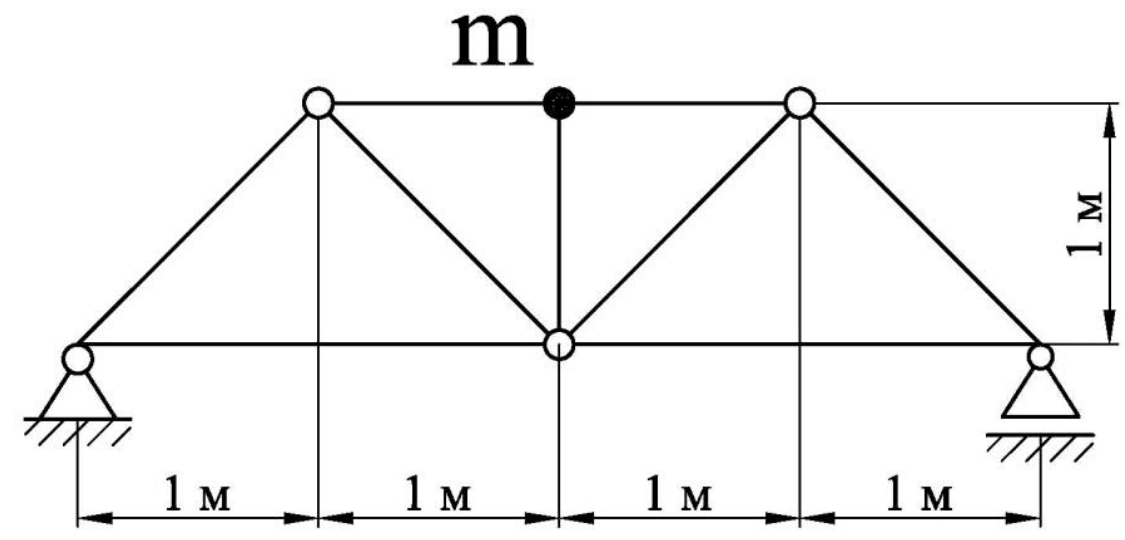

Figure 2. Scheme of the steelwork

\section{Solution}

1. The number of rods and nodal points are denoted on the scheme of the steelwork, the length of the rods are determined: $\ell_{1}=\ell_{6}=2 \mathrm{~m}, \ell_{2}=\ell_{3}=\ell_{7}=\ell_{8}=1.41 \mathrm{~m}, \ell_{4}=\ell_{5}=\ell_{9}=1 \mathrm{~m}$ (Fig. 3).

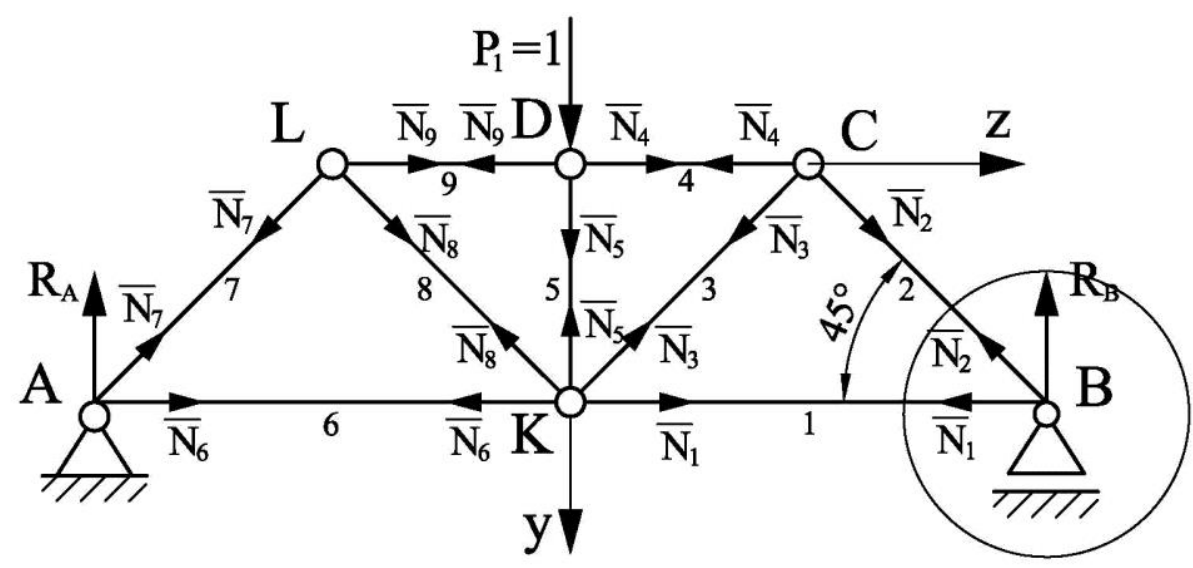

Figure 3. Diagram for determining the force at the rods of steelworks from the action of a single force $P_{1}=1$

2. Vertical single force $P_{1}=1$ is applied to the steelwork at the location of the engine (node D) and the reaction of the steelwork $R_{A}$ and $R_{B}$ are determined from this force (see Fig. 3):

$$
\left\{\begin{array}{l}
\sum M_{A}=-P_{1} \cdot 2+R_{B} \cdot 4=0 ; \quad R_{B}=\frac{P_{1} \cdot 2}{4}=\frac{1 \cdot 2}{4}=0.5 ; \\
\sum M_{B}=P_{1} \cdot 2-R_{A} \cdot 4=0 ; \quad R_{A}=\frac{P_{1} \cdot 2}{4}=\frac{1 \cdot 2}{4}=0.5 .
\end{array}\right.
$$

Verification: $\sum P_{y}=P_{1}-R_{A}-R_{B}=1-0.5-0.5=0$. Responses are correct.

$$
\begin{cases}\sum P_{y}=-R_{B}-\bar{N}_{2} \cdot \sin 45^{0}=0 ; & \bar{N}_{2}=-\frac{R_{B}}{\sin 45^{0}}=-\frac{0.5}{0.71}=-0.71 ; \\ \sum P_{z}=-\bar{N}_{1}-\bar{N}_{2} \cdot \cos 45^{0}=0 ; & \bar{N}_{1}=-\bar{N}_{2} \cdot \cos 45^{0}=0.71 \cdot 0.71=+0.5 .\end{cases}
$$

Signs indicate that the rod 1 is stretched and the rod 2 is compressed.

4. Consistently transfer to nodes $C, D, L, A$ and similarly determine all other forces: $\overline{N_{3}}=+0.71 ; \overline{N_{4}}=-1 ; \overline{N_{5}}=+1 ; \overline{N_{9}}=-1 ; \overline{N_{8}}=+0.71 ; \overline{N_{7}}=-0.71 ; \overline{N_{6}}=+0.5$.

5. For verification, equilibrium of the node $K$ is considered: 


$$
\left\{\begin{aligned}
\sum P_{y} & =\bar{N}_{5}-\bar{N}_{3} \cdot \sin 45^{0}-\bar{N}_{8} \cdot \sin 45^{0}=1-0.71 \cdot 0.71-0.71 \cdot 0.71=1-0.5-0.5=0 ; \\
\sum P_{z} & =\bar{N}_{1}-\bar{N}_{6}+\bar{N}_{3} \cdot \cos 45^{0}-\bar{N}_{8} \cdot \cos 45^{0}=0.5-0.5+0.71 \cdot 0.71-0.71 \cdot 0.71= \\
& =0.5-0.5+0.5-0.5=0 .
\end{aligned}\right.
$$

Forces in all rods are found correctly.

6. When horizontal unit force $P_{2}=1$ is applied to the steelwork at the location of the engine (node $D$ ) and from the reaction of the steelwork and the force in the rods is determined in the same way (Fig. 4).

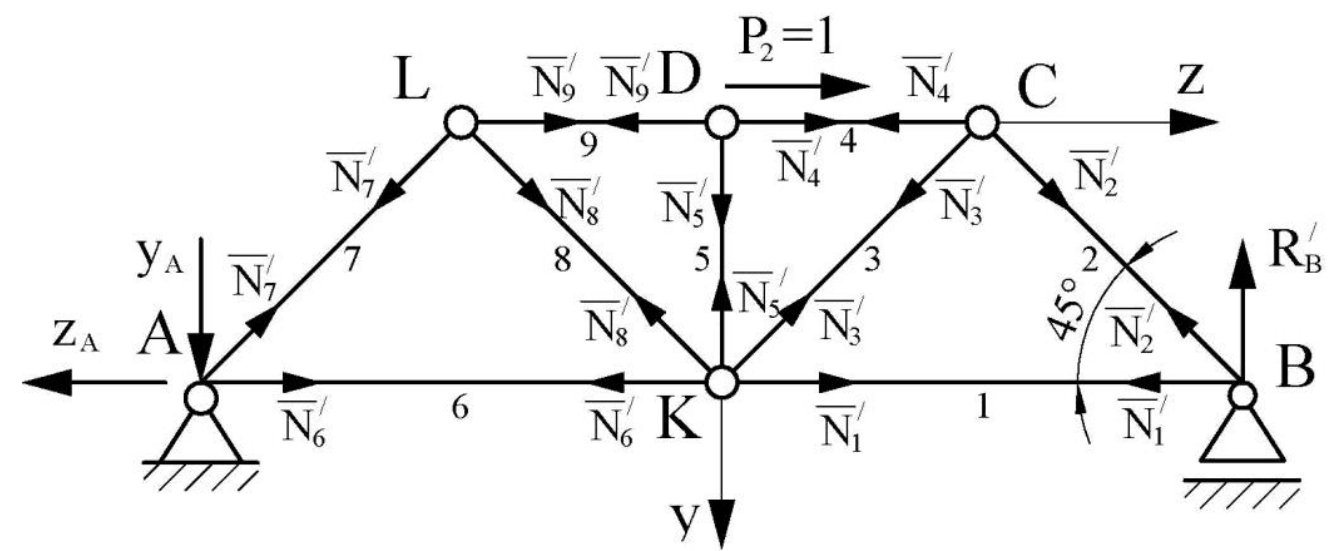

Figure 4. Scheme for determining the force in the steelwork from the action of a single force $P_{2}=1$

This time it is: $y_{A}=0.25 ; \quad z_{A}=1 ; \quad R_{B}^{\prime}=0.25 ; \quad \overline{N_{1}^{\prime}}=+0.25 ; \quad \overline{N_{2}^{\prime}}=-0.35 ; \quad \overline{N_{3}^{\prime}}=+0.35$; $\overline{N_{4}^{\prime}}=-0.5 ; \overline{N_{5}^{\prime}}=0 ; \overline{N_{9}^{\prime}}=+0.5 ; \overline{N_{8}^{\prime}}=-0.35 ; \overline{N_{7}^{\prime}}=+0.35 ; \overline{N_{6}^{\prime}}=+0.75$.

7. The obtained values of internal forces are presented in Table 1 as well as the steelwork rigidity is determined.

Table 1 shows that the value of $\delta_{12}$ is positive. This indicates that the directions of unit force $P_{2}=1$ and the $z$ axis are chosen correctly [14].

8. Analyzing the obtained data (see Table 1), we see that the largest force by the module during engine operation takes place in the rod 4 , which is dangerous in terms of strength. The law of changing these forces is:

$$
N_{4}(t)=\bar{N}_{4} \cdot P_{1}(t)+\bar{N}_{4}^{\prime} \cdot P_{2}(t)=-1 \cdot P_{1}(t)-0.5 \cdot P_{2}(t),
$$

where $P_{1}(t)$ and $P_{2}(t)$ are the laws of change of forces $P_{1}$ and $P_{2}$, which are implicitly determined by the computer.

9. The data obtained (see Table 1) indicate that the rod 4, which has the largest compressive forces, and the rod 2, which compression forces are slightly smaller and the length is longer are potentially dangerous from the point of view of loss of stability.

The law of change of force in the rod 2:

$$
N_{2}(t)=\bar{N}_{2} \cdot P_{1}(t)+\bar{N}_{2}^{\prime} \cdot P_{2}(t)=-0.71 \cdot P_{1}(t)-0.35 \cdot P_{2}(t) \text {. }
$$

10. The cross-sectional area of the cross sections of the rods of the steelwork is determined:

$$
\begin{gathered}
F=\frac{\pi \cdot d^{2}}{4} \cdot\left[1-\left(1-2 \cdot \frac{s}{d}\right)^{2}\right] . \\
F=\frac{3.14 \cdot 0.1^{2}}{4} \cdot\left[1-\left(1-2 \cdot \frac{0.005}{0.1}\right)^{2}\right]=1.49 \cdot 10^{-3} \mathrm{~m}^{2} .
\end{gathered}
$$

Table 1

Determination of steelwork rigidity indicators

\begin{tabular}{|c|c|c|c|c|c|c|}
\hline $\begin{array}{l}\text { Rod } \\
\text { number }\end{array}$ & $\overline{N_{i}}$ & $\overline{N_{i}^{\prime}}$ & $\ell_{i}, \mathrm{~m}$ & $\left(\overline{N_{i}}\right)^{2} \cdot \ell_{i}, \mathrm{~m}$ & $\left(\overline{N_{i}^{\prime}}\right)^{2} \cdot \ell_{i}, \mathrm{M}$ & $\overline{N_{i}} \cdot \overline{N_{i}^{\prime}} \cdot \ell_{i}, \mathrm{M}$ \\
\hline 1 & +0.5 & +0.25 & 2 & 0.5 & 0.125 & 0.25 \\
\hline
\end{tabular}




\begin{tabular}{|c|c|c|c|c|c|c|}
\hline 2 & -0.71 & -0.35 & 1.41 & 0.711 & 0.173 & 0.35 \\
\hline 3 & +0.71 & +0.35 & 1.41 & 0.711 & 0.173 & 0.35 \\
\hline 4 & -1 & -0.5 & 1 & 1 & 0.25 & 0.5 \\
\hline 5 & -1 & 0 & 1 & 1 & 0 & 0 \\
\hline 6 & +0.5 & +0.75 & 2 & 0.5 & 1.25 & 0.75 \\
\hline 7 & -0.71 & +0.35 & 1.41 & 0.711 & 0.173 & -0.35 \\
\hline 8 & +0.71 & -0.35 & 1.41 & 0.711 & 0.173 & -0.35 \\
\hline 9 & -1 & +0.5 & 1 & 1 & 0.25 & -0.5 \\
\hline & & & & $\sum=6.844$ & $\sum=2.442$ & $\sum=1$ \\
\hline & & & & $\delta_{11}=\frac{6.844}{E F}$ & $\delta_{22}=\frac{2.442}{E F}$ & $\delta_{12}=\delta_{21}=\frac{1}{E F}$ \\
\hline
\end{tabular}

11. The expressions for steelwork rigidity indices are introduced into the calculation program [14] (see Table 1), as well as the law of change of forces (6) and the value of $F$, so we obtain for the $\operatorname{rod} 4$ :

Similarly for the rod 2 :

$$
\sigma_{\min }=-2.24 \cdot 10^{7} \mathrm{~Pa}=-22.4 \mathrm{MPa}, \omega_{1}=145.27 \mathrm{~s}^{-1}, \omega_{2}=258.751 \mathrm{~s}^{-1} \text { (Fig. 5). }
$$

$$
\sigma_{\min }=-1.589 \cdot 10^{7} \mathrm{~Pa}=-15.89 \mathrm{MPa}, \omega_{1}=145.27 \mathrm{~s}^{-1}, \omega_{2}=258.751 \mathrm{~s}^{-1} .
$$

12. The rod 4 is verified for compliance with the strength condition:

$$
\left|\sigma_{\min }\right| \leq[\sigma] \text {. }
$$

In our case $\left|\sigma_{\min }\right|=22.4 \mathrm{MPa}<[\sigma]$, so the strength of the rod 4 and of the steelwork as a whole is ensured.

13. The flexibility of the compressed rods is defined:

$$
\lambda=\frac{\mu \cdot \ell}{i_{\min }},
$$

where $\mu$ is the cast ratio of the rod;

$\ell$ is the length of the rod;

$i_{\min }$ is the minimum radius of inertia of the cross-section of the rod.

Since the ends of the rods in steelwork are hinged, $\mu=1[1, \mathrm{p} .504]$. The cross section of the rods is circular, therefore:

$$
i_{\text {min }}=i_{x}=i_{y}=i_{a x} ; \quad i_{a x}=\sqrt{\frac{J_{a x}}{F}} ; \quad J_{a x}=\frac{\pi \cdot d^{4}}{64} \cdot\left[1-\left(1-2 \cdot \frac{s}{d}\right)^{4}\right] .
$$

With this in mind:

$$
\begin{gathered}
J_{a x}=\frac{3.14 \cdot 0.1^{4}}{64} \cdot\left[1-\left(1-2 \cdot \frac{0.005}{0.1}\right)^{4}\right]=1.687 \cdot 10^{-6} \mathrm{~m}^{4} ; \\
i_{a x}=\sqrt{\frac{1.687 \cdot 10^{-6}}{1.49 \cdot 10^{-3}}}=0.034 \mathrm{~m} .
\end{gathered}
$$

So for the rods 4 and 2 , respectively, there is:

$$
\begin{aligned}
& \lambda=\frac{1 \cdot 1}{0.034}=29.4 ; \\
& \lambda=\frac{1 \cdot 1.41}{0.034}=41.5 .
\end{aligned}
$$




$$
\begin{aligned}
& \mathrm{g}:=9.81 \quad \mathrm{~m}:=2000 \quad \mathrm{H}:=0.3 \cdot \mathrm{m} \cdot \mathrm{g} \quad \omega:=31.4 \quad \mathrm{E}:=2 \cdot 10^{11} \\
& \mathrm{~d}:=100 \cdot 10^{-3} \quad \mathrm{~F}:=0.149 \cdot \mathrm{d}^{2} \quad \mathrm{~F}=1.49 \times 10^{-3} \\
& \delta 11:=\frac{6.844}{\mathrm{E} \cdot \mathrm{F}} \quad \delta 22:=\frac{2.442}{\mathrm{E} \cdot \mathrm{F}} \quad \delta 12:=\frac{1.0}{\mathrm{E} \cdot \mathrm{F}} \quad \delta 21:=\delta 12 \\
& \delta 11=2.297 \times 10^{-8} \quad \delta 22=8.195 \times 10^{-9} \quad \delta 21=3.356 \times 10^{-9} \quad \delta 12=3.356 \times 10^{-9} \\
& \mathrm{a}:=\frac{\delta 22}{(\delta 12 \cdot \delta 21-\delta 11 \cdot \delta 22) \cdot \mathrm{m}} \quad \mathrm{b}:=\frac{\delta 12}{(\delta 12 \cdot \delta 21-\delta 11 \cdot \delta 22) \cdot \mathrm{m}} \quad \mathrm{d}:=\mathrm{g} \cdot\left[1+\frac{\delta 11 \cdot \delta 22-\delta 12 \cdot \delta 21}{(\delta 12 \cdot \delta 21-\delta 11 \cdot \delta 22)}\right] \\
& \mathrm{k}:=\frac{\delta 21}{(\delta 11 \cdot \delta 22-\delta 12 \cdot \delta 21) \cdot \mathrm{m}} \quad \mathrm{n}:=\frac{\delta 11}{(\delta 11 \cdot \delta 22-\delta 12 \cdot \delta 21) \cdot \mathrm{m}} \\
& \text { Given } \\
& y^{\prime \prime}(t)-a \cdot y(t)+b \cdot z(t)=\frac{H}{m} \cdot \cos (\omega \cdot t)+d \quad z^{\prime \prime}(t)-k \cdot y(t)+n \cdot z(t)=\frac{H}{m} \cdot \sin (\omega \cdot t) \\
& y(0)=0 \quad y^{\prime}(0)=0 \quad z(0)=0 \quad z^{\prime}(0)=0 \\
& \left(\begin{array}{l}
\mathrm{y} \\
\mathrm{z}
\end{array}\right):=\operatorname{Odesolve}\left[\left(\begin{array}{l}
\mathrm{y} \\
\mathrm{z}
\end{array}\right), \mathrm{t}, 4\right] \quad \mathrm{t}:=0,0.002 . .4 \\
& \mathrm{P} 1(\mathrm{t}):=\mathrm{m} \cdot \mathrm{g}+\frac{\mathrm{z}(\mathrm{t})}{\delta 21}-\frac{\mathrm{y}(\mathrm{t}) \cdot \delta 21-\mathrm{z}(\mathrm{t}) \cdot \delta 11}{\delta 21^{2}-\delta 22 \cdot \delta 11} \cdot \frac{\delta 22}{\delta 21} \quad \mathrm{P} 2(\mathrm{t}):=\frac{\mathrm{y}(\mathrm{t}) \cdot \delta 21-\mathrm{z}(\mathrm{t}) \cdot \delta 11}{\delta 21^{2}-\delta 22 \cdot \delta 11} \\
& \mathrm{~N}(\mathrm{t}):=-\mathrm{P} 1(\mathrm{t}) \cdot 1-\mathrm{P} 2(\mathrm{t}) \cdot 0.5 \\
& \begin{array}{l}
\text { ORIGIN }:=1 \quad \mathrm{i}:=1 . .4000 \quad \mathrm{t}_{\mathrm{i}}:=0+\frac{\mathrm{i}}{1000} \quad \mathrm{Y}_{\mathrm{i}}:=\mathrm{y}\left(\mathrm{t}_{\mathrm{i}}\right) \quad \mathrm{Z}_{\mathrm{i}}:=\mathrm{z}\left(\mathrm{t}_{\mathrm{i}}\right) \\
\mathrm{PP}_{\mathrm{i}}:=\mathrm{P} 1\left(\mathrm{t}_{\mathrm{i}}\right) \quad \quad \mathrm{PP} 2_{\mathrm{i}}:=\mathrm{P} 2\left(\mathrm{t}_{\mathrm{i}}\right)
\end{array} \\
& \text { Nmax }:=\max (\mathrm{NN}) \quad \mathrm{Nmax}=-5.901 \times 10^{3} \mathrm{Nmin}:=\min (\mathrm{NN}) \quad \mathrm{Nmin}=-3.338 \times 10^{4} \\
& \sigma \min :=\frac{\mathrm{Nmin}}{\mathrm{F}} \quad \sigma \mathrm{min}=-2.24 \times 10^{7} \\
& \omega \mathrm{R} 1:=\frac{\sqrt{2}}{\sqrt{\mathrm{m} \cdot(\delta 11+\delta 22)+\mathrm{m} \cdot \sqrt{(\delta 11+\delta 22)^{2}-4 \cdot\left(\delta 11 \cdot \delta 22-\delta 12^{2}\right)}}} \quad \omega \mathrm{R} 1=145.27 \\
& \omega R 2:=\frac{\sqrt{2}}{\sqrt{m \cdot(\delta 11+\delta 22)-m \cdot \sqrt{(\delta 11+\delta 22)^{2}-4 \cdot\left(\delta 11 \cdot \delta 22-\delta 12^{2}\right)}}} \quad \omega R 2=258.751
\end{aligned}
$$

Figure 5 - Dynamic calculation of the rod 4

14. Rods 4 and 2 are verified for stability.

The stability condition has the form [4]:

$$
\left|\sigma_{\min }\right| \leq \varphi \cdot[\sigma]
$$

where $\varphi$ is the coefficient of reduction of the basic allowable stress, which depends on the flexibility of the $\operatorname{rod} \lambda$.

In the corresponding table [1, p. 508] we find for the rod 4: $\varphi=0.941$, and for the rod 2: $\varphi=0.916$. Then the allowable stresses for the stability of the rods 4 and 2 respectively are:

$$
\begin{aligned}
& \varphi \cdot[\sigma]=0.941 \cdot 160=150.56 \mathrm{MPa}, \\
& \varphi \cdot[\sigma]=0.916 \cdot 160=146.56 \mathrm{MPa} .
\end{aligned}
$$

Comparing the value of $\left|\sigma_{\min }\right|$ in the rods 4 and 2 with the permissible stability, we see that the condition of stability of these rods and the steelwork as a whole is fulfilled.

15. Resonance verification of the steelwork. 
Resonance arises from the coincidence of the circulating frequency of the disturbing force and the resonant frequencies of the structure: $\omega=\omega_{1}$, or $\omega=\omega_{2}$. In our case, $\omega=31.4 \mathrm{~s}^{-1}, \omega_{1}=145.27 \mathrm{~s}^{-1}$, $\omega_{2}=258.751 \mathrm{~s}^{-1}$, so there is no resonance found.

There is a point of view [1, etc.] that in order to reliably prevent resonance, the value $\omega$ must be at least $30 \%$ less than the value $\omega_{1}$ :

$$
\omega \leq 0,7 \omega_{1}
$$

Let's verify this condition too.

In our case: $0.7 \omega_{1}=0.7 \cdot 145.27=101.689 \mathrm{~s}^{-1}$, which is greater than $\omega$. So this condition is also fulfilled. Verifying this condition with respect to $\omega_{2}$ makes no sense, since $\omega_{2}>\omega_{1}$.

Thus, all the conditions of the task are fulfilled.

Finally, we compare the results with those published in [14], which gives an example of a similar calculation of the same steelwork using a one-dimensional model that takes into account only vertical oscillations. In that example, the resonant frequency is up to $46.577 \mathrm{~s}^{-1}$, and the highest modulus compression stresses in the rod 4 are $20.4 M P a$.

As we can see, the one-dimensional model significantly reduces the results of the calculations, especially regarding the determination of the resonance frequencies.

Example 2. Ignoring the resistance of the medium, it is necessary to select the required crosssectional dimensions of pipes with a ratio $s / d=0.2$ for the steelwork shown in figure 2. Pipe material is steel St.3, $[\sigma]=160 \mathrm{MPa}$. Weight of statically unbalanced electric motor installed on the steelwork $m=1400 \mathrm{~kg}$, its circular speed $\omega=104.667 \mathrm{c}^{-1}(1000 \mathrm{rpm})$, the module created by it disturbing force $H=0.3 \mathrm{mg}$. Determine the resonant frequencies of the design.

\section{Solution}

1. - 9. Paragraphs 1 to 9 are the same as in Example 1.

10. From formulas (8), (10), (11) and the conditions of example 2 , the values of $F, J_{a x}, i_{a x}$, and $\lambda$ are expressed through the outer diameter of the pipe $d$ :

$$
\begin{gathered}
F=\frac{\pi \cdot d^{2}}{4} \cdot\left[1-\left(1-2 \cdot \frac{s}{d}\right)^{2}\right]=\frac{3.14 \cdot d^{2}}{4} \cdot\left[1-(1-2 \cdot 0.2)^{2}\right]=0.502 \cdot d^{2} \\
J_{a x}=\frac{\pi \cdot d^{4}}{64} \cdot\left[1-\left(1-2 \cdot \frac{s}{d}\right)^{4}\right]=\frac{3.14 \cdot d^{4}}{64} \cdot\left[1-(1-2 \cdot 0.2)^{4}\right]=0.043 \cdot d^{4} \\
i_{a x}=\sqrt{\frac{0.043 \cdot d^{4}}{0.502 \cdot d^{2}}}=0.292 \cdot d \\
\lambda=\frac{\mu \cdot \ell}{i_{a x}}=\frac{1 \cdot \ell}{0.292 \cdot d}=3.425 \cdot \frac{\ell}{d} .
\end{gathered}
$$

11. From the condition of strength at static loading of the steelwork by the weight of idle engine, the desired value of $d$ is determined:

$$
\begin{gathered}
F=0.502 \cdot d^{2} \geq \frac{|\bar{N}|_{\max } \cdot m g}{[\sigma]}=\frac{1 \cdot 1400 \cdot 9.81}{160}=85.8 \mathrm{~mm}^{2} ; \\
d \geq \sqrt{\frac{85.8}{0.502}}=13.1 \mathrm{~mm} .
\end{gathered}
$$

From the normal series of linear dimensions ( $R a$ 20, GOST $6636-69)$ [15] we accept: $d=14$ $\mathrm{mm}$. From this a dynamic calculation starts, which consists of successive strength and stability verifications of the rods 4 and 2 at values $d \geq 14 \mathrm{~mm}$ according to the method described in example 1 , taking into account expressions (16) - (19). The results of the dynamic calculation are presented in Tables 2 and 3.

As can be seen from Tables 2 and 3, strength and durability of both rods, as well as of the steelwork as a whole, is provided by pipe $40 \times 8 \mathrm{~mm}$. In this case, the resonance frequencies are: $\omega_{1}=127.481 \mathrm{~s}^{-1}, \omega_{2}=227.065 \mathrm{~s}^{-1}$, which is quite far from the resonance. The values $d=32 \mathrm{~mm}$ and $d=18 \mathrm{~mm}$ are the closest to it, at which the stresses in both rods are the greatest. 
Results of dynamic calculation of the rod 4

Table 2

\begin{tabular}{|c|c|c|c|c|c|c|c|c|}
\hline \multirow[b]{2}{*}{$\begin{array}{l}d, \\
m m\end{array}$} & \multirow[b]{2}{*}{$\begin{array}{c}F, \\
m m^{2}\end{array}$} & \multicolumn{5}{|c|}{$N(t)=-P_{1}(t) \cdot 1-P_{2}(t) \cdot 0.5$} & \multirow[b]{2}{*}{$\begin{array}{l}\omega_{1}, \\
s^{-1}\end{array}$} & \multirow[b]{2}{*}{$\begin{array}{l}\omega_{2}, \\
s^{-1}\end{array}$} \\
\hline & & $\begin{array}{c}\left|N_{\min }\right| \\
N\end{array}$ & $\begin{array}{l}\sigma_{\min \mid} \mid, \\
M P a\end{array}$ & $\lambda$ & $\varphi$ & $\begin{array}{l}\varphi \cdot[\sigma], \\
M P a\end{array}$ & & \\
\hline 14 & 98.4 & 18660 & 189.7 & 245 & $<0.19$ & $<30.4$ & 44.618 & 79.473 \\
\hline 16 & 128.5 & 22950 & 178.6 & 214 & $<0.19$ & $<30.4$ & 50.992 & 90.826 \\
\hline 18 & 162.6 & 61880 & 380.5 & 190 & 0.210 & 33.6 & 57.366 & 102.179 \\
\hline 20 & 200.8 & 30790 & 153.3 & 171 & 0.257 & 41.1 & 63.740 & 113.533 \\
\hline 22 & 243.0 & 25690 & 105.7 & 156 & 0.302 & 48.3 & 70.114 & 124.886 \\
\hline 25 & 313.8 & 27750 & 88.4 & 137 & 0.372 & 59.5 & 79.675 & 141.916 \\
\hline 28 & 393.6 & 38760 & 98.5 & 122 & 0.440 & 70.4 & 89.237 & 158.946 \\
\hline 32 & 514.0 & 181600 & 353.3 & 107 & 0.544 & 87.0 & 101.985 & 181.652 \\
\hline 36 & 650.6 & 67570 & 103.9 & 95 & 0.645 & 103.2 & 114.733 & 204.359 \\
\hline 40 & 803.2 & 41400 & 51.5 & 86 & 0.714 & 114.2 & 127.481 & 227.065 \\
\hline
\end{tabular}

Results of dynamic calculation of the rod 2

Table 3

\begin{tabular}{|c|c|c|c|c|c|c|c|c|}
\hline \multirow{2}{*}{$\begin{array}{c}d, \\
m m\end{array}$} & \multirow{2}{*}{$\begin{array}{c}F, \\
m^{2}\end{array}$} & $\begin{array}{c}\left|N_{\min }\right|, \\
N\end{array}$ & $\begin{array}{c}\left|\sigma_{\min }\right|, \\
M p a\end{array}$ & $\lambda$ & $\varphi$ & $\begin{array}{c}\varphi \cdot[\sigma], \\
M P a\end{array}$ & $\begin{array}{c}\omega_{1}, \\
s^{-1}\end{array}$ & $\begin{array}{c}\omega_{2}, \\
s^{-1}\end{array}$ \\
\hline 14 & 98.4 & 13190 & 134.1 & 345 & $<0.19$ & $<30.4$ & 44.618 & 79.473 \\
\hline 16 & 128.5 & 16170 & 125.8 & 302 & $<0.19$ & $<30.4$ & 50.992 & 90.826 \\
\hline 18 & 162.6 & 43110 & 265.1 & 268 & $<0.19$ & $<30.4$ & 57.366 & 102.179 \\
\hline 20 & 200.8 & 21620 & 107.7 & 241 & $<0.19$ & $<30.4$ & 63.740 & 113.533 \\
\hline 22 & 243.0 & 18140 & 74.7 & 220 & $<0.19$ & $<30.4$ & 70.114 & 124.886 \\
\hline 25 & 313.8 & 19660 & 62.7 & 193 & 0.204 & 32.6 & 79.675 & 141.916 \\
\hline 28 & 393.6 & 27470 & 69.8 & 172 & 0.254 & 40.6 & 89.237 & 158.946 \\
\hline 32 & 514.0 & 128800 & 250.6 & 151 & 0.317 & 50.7 & 101.985 & 181.652 \\
\hline 36 & 650.6 & 47910 & 73.6 & 134 & 0.384 & 61.4 & 114.733 & 204.359 \\
\hline 40 & 803.2 & 29360 & $\mathbf{3 6 . 6}$ & 121 & 0.445 & $\mathbf{7 1 . 2}$ & 127.481 & 227.065 \\
\hline
\end{tabular}

Conclusions. An advanced technique of power calculations of flat steelworks is developed, based on previously created and implemented in Mathcad system of a simplified two-dimensional model of forced oscillations, which significantly improves the accuracy and reliability of determination of dynamic forces, stresses and resonance frequencies in comparison with the common in practice model that takes into account only vertical fluctuations, ignoring horizontal ones.

The developed technique allows to determine the maximum dynamic forces and stresses in an oscillating steelwork, to calculate its resonant frequencies, to verify the fulfillment of the conditions of strength and stability, to select the required cross-sectional dimensions of the rods in order to guarantee these conditions.

The methodology is illustrated by the examples of test and design calculations and can be recommended to students and manufacturing professionals for use in educational and engineering practice.

In the future, it is appropriate to create a cross-platform computer program that would cover all stages of the calculation by the developed method, and thus simplify and accelerate it as much as possible.

\section{References}

1. Дарков А. В. Сопротивление материалов: Учеб. для техн. вузов / А. В. Дарков, Г. С. Шпиро. - М.: Высш. шк., 1989. - 624 с.

2. Икрин В.А. Сопротивление материалов с элементами теории упругости и пластичности / В.А. Икрин. - М.: Изд. АСВ, 2004. - 424 с. 
3. Грес П.В. Руководство к решению задач по сопротивлению материалов: Учеб. пособие для ВУЗов / П.В. Грес. - М.: Высш. шк., 2004. - 135 с.

4. Писаренко Г. С. Опір матеріалів: Підр. для техн. ВНЗ / Г. С. Писаренко, О. Л. Квітка, Е. С. Уманський. - К.: Вища шк., 2004. - 655 с.

5. Шевченко Ф. Л. Курс опору матеріалів. Порада до вивчення теорії та розв'язання задач: Навч. посібник / Ф. Л. Шевченко. - Донецьк: ДонНТУ, 2013.- 260 с.

6. Purushothama Rai. P. Strength of Materials / P.Rai. Purushothama, V.Ramasamy.- Pearson India, 2012. - $1039 \mathrm{p}$.

7. Поляков А. А. Строительная механика: Учеб. пособие / А. А. Поляков, Ф. Г. Лялина, Р. Г. Игнатов. - Екатеринбург: УрФУ, 2014. - 424 с.

8. Olsson K.- G. Structural Mechanics: Modelling and Analysis of Frames and Steelworkes / K.- G. Olsson, O. Dahlblom. - John Wiley \& Sons, 2016. - 344 p.

9. Lacarbonara W. Nonlinear Structural Mechanics: Theory, Dynamical / W. Lacarbonara. Springer Science \& Business Media, 2013. - 802 p.

10. Carpinteri A. Structural Mechanics Fundamentals / A.Carpinteri. - CRC Press, 2013.- 512p.

11. Carpinter A. Advanced Structural Mechanics / A. Carpinter . - CRC Press, 2017. - 531 p.

12. Ламси Б. Б. Сборник задач и упражнений по динамике стержневых систем: Учеб. пособие / Б. Б. Ламси и др. - Н.Новгород: ННГАСУ, 2016. - 96 с.

13. Уфимцев Е.М. Моделирование нелинейных колебаний плоских ферм при нестационарных процесах на основе метода временного анализа / Е.М. Уфимцев. - Челябинск: Вестник ЮУрГУ, серия “Строительство и архитектура”, 2017, № 1, С. 20 - 33.

14. Холодняк Ю.С. Упрощённая методика силового расчёта плоских рам в условиях вынужденных колебаний / Ю. С. Холодняк, С. В. Подлесный, С. В. Капорович. // Вісник Донбаської державної машинобудівної академії: Збірник наукових праць. - Краматорськ: ДДМА, 2018. - № 1(43). - С.198-213.

15. Kholodniak Yu.S. Elaboration of a Methodology of Pover Calculations of Flat Frames Under Conditions of Forced Oscillations / Yu.S. Kholodniak, S.V. Kaporovych, Ye.D. Korotenko // Contemporary Innovation Technique of Engineering Personnel Training for the Mining and Transport Industry 2019 (CITEPTMTI'2019). Conference Proceedings (2019). - Ukraine, Dnipro: NTUDP.- P. 92-100.

16. Кутовий Л. В. Збірник розрахунково - графічних завдань з курсу "Опір матеріалів" (для студентів всіх механічних спеціальностей денної форми навчання) / Л. В. Кутовий та ін. Краматорськ: ДДМА, 2007. - 220 с.

Холодняк Ю.С., Подлєсний С.В., Капорович С.В., Коротенко Є.Д.

Донбаська державна машинобудівна академія

ПРО ЗАСТОСУВАННЯ СПРОЩЕНОЇ ДВОВИМІРНОЇ МОДЕЛІ ВИМУШЕНИХ

КОЛИВАНЬ ДО СИЛОВОГО АНАЛІЗУ ПЛОСКИХ МЕТАЛОКОНСТРУКЦІЙ

Виконано аналіз існуючих методів силового розрахунку ферм, які перебувають під дією вимушених коливань. При розгляданні вимушених коливань плоских ферм застосовуються двовимірні моделі, які є складними для широкого практичного використання. Їх реалізація потребує поглибленої математичної підготовки і складних обчислювальних засобів. Метою даної роботи є розробка спрощеної двомірної математичної моделі вимушених коливань плоских ферм з наступним використанням иієї моделі в їх силових розрахунках. Математична модель, що запропонована в роботі, описує коливання невагомої ферми з точковою масою при одночасній дії на них вертикальної й горизонтальної гармонійних збурюючих сил. У основу моделі покладений метод сил, що встановлює зв'язок переміщень ферми з силами, які на неї діють. Разом з моделлю отримані залежності для обчислення резонансних частот коливальної системи. Виконані розробки дозволяють визначати динамічні характеристики коливального процесу і розраховувати ферми на міцність, жорсткість та стійкість.

Ключові слова: плоскі ферми, вимушені коливання, математична модель, резонансні частоти, силові розрахунки.

Холодняк Ю.С., Подлесный С.В., Капорович С.В., Коротенко Е.Д.

Донбасская государственная машиностроительная академия

О ПРИМЕНЕНИИ УПРОЩЕННОЙ ДВУМЕРНОЙ МОДЕЛИ ВЫНУЖДЕННЫХ КОЛЕБАНИЙ К СИЛОВОМУ АНАЛИЗУ ПЛОСКИХ МЕТАЛЛОКОНСТРУКЦИЙ

(C) Yu.S. Kholodnyak, S.V. Podlesny, S.V. Kaporovych, Ye.D. Korotenko 
Выполнен анализ существующих методов силового расчета ферм, находящихся под действием вынужденных колебаний. При рассмотрении вынужденных колебаний плоских ферм применяются двумерные модели, которые являются сложными для широкого практического использования. Целью данной работы является разработка упрощенной двухмерной математической модели вынужденных колебаний плоских ферм с последуюшим использованием этой модели в их силовых расчетах. Математическая модель, предложенная в работе, описывает колебания невесомого фермы с точечной массой при одновременном действии на них вертикальной и горизонтальной гармонических возмущающих сил. В основу модели положен метод сил, устанавливающий связь перемещений фермы с силами, которые на нее действуют. Вместе с моделью получены зависимости для вычисления резонансных частот колебательной системы. Выполненные разработки позволяют определить динамические характеристики колебательного процесса и рассчитывать фермы на прочность, жесткость и устойчивость.

Ключевые слова: плоские фермы, вынужденные колебания, математическая модель, резонансные частоты, силовые расчеты. 